\title{
Native Welfare Losses from High Skilled Immigration
}

\author{
ALEXANDER KEMNITZ
}

CESIFO WORKING PAPER NO. 2409

CATEGORY 4: LABOUR MARKETS

SEPTEMBER 2008

\footnotetext{
An electronic version of the paper may be downloaded

- from the SSRN website: www.SSRN.com

- from the RePEc website:

- from the CESifo website: 


\title{
Native Welfare Losses from High Skilled Immigration
}

\begin{abstract}
This paper explores the effects of high skilled immigration to a host country with unionized low skilled labor and an unemployment insurance scheme. We show that such immigration can create a negative immigration surplus due to adverse effects on low skilled employment, provided that fiscal redistribution is not too intense and the elasticity between high and low skilled labor is high as empirical evidence suggests.
\end{abstract}

JEL Code: F22, J5, H53, J61, J65.

Keywords: immigration, trade union, unemployment, welfare state, elasticity of substitution.

\author{
Alexander Kemnitz \\ TU Dresden \\ Department of Economics \\ 01062 Dresden \\ Germany \\ alexander.kemnitz@tu-dresden.de
}

September 2008

I would like to thank CES Munich for the very generous hospitality and support during my visit. 


\section{Introduction}

While the impact of the international mobility of the highly skilled on sending countries is disputed continuously (Bhagwati \& Hamada, 1974; Mountford, 1997; Haupt \& Janeba, 2008), positive effects on receiving countries are taken more or less for granted. High skilled immigrants are most welcomed; not only because of their fiscal contributions, but also because of the expected creation of employment in other, in particular distorted, labor market segments (OECD, 2002, Chiswick, 2007). ${ }^{1}$

Somewhat surprisingly, the interaction between high skilled immigration and distortions in other labor market segments has received little investigation hitherto. The present paper builds a simple model addressing the question how high skilled immigration affects a host economy with low skilled unemployment. Featuring some fundamental characteristics of European labor markets, unemployment results from the existence of trade unions and an unemployment insurance scheme.

Within this framework, we show that high skilled immigration is not necessarily beneficial, but can indeed impose a burden on the aggregate income of the native population. This loss is based on the empirically corroborated fact that high and low skilled labor are close, albeit imperfect substitutes in the production process (Johnson, 1997; Card \& Lemieux, 2001). With this property, we find that a higher number of high skilled workers reduces total low skilled employment as low skilled labor demand, determining unions' wage markup, becomes less elastic. This rise in unemployment is even reinforced by additional fiscal redistribution exerted by the high skilled. The resulting loss in aggregate native gross income dominates the direct fiscal contributions by the high skilled when fiscal redistribution is not too high.

To the best of our knowledge, these insights are novel to the literature. The only other study exhibiting negative effects of high skilled immigrants we are aware of is Michael (2006). However, that result is based on a quite different mechanism. In a

1 However, the materialization of these virtues hinges on the high skilled really coming to the respective country which obviously depends on its economic appeal. The international competition for the high skilled is therefore expected to reduce equilibrium redistribution and hence fiscal effects in the receiving countries as well (Wildasin, 2000; Poutvaara, 2000; Andersson \& Konrad, 2003). This adjustment, which would render the above-mentioned employment aspect even more relevant, is not our concern here. Rather, we investigate how high skilled immigration operates on a country which is appealing enough to attract these people. 
full employment setting, Michael (2006) shows that the admittance of high skilled immigrants can trigger additional low skilled immigration on such a scale that the positive fiscal effects of the former group are dominated by the negative fiscal effects of the latter. Our result is however not based on these fiscal, but on the employment consequences instead.

The paper is organized as follows. Section II derives the labor market equilibrium of the host economy. Section III addresses the effects of high skilled immigration on the labor market and the overall position of natives. Section IV offers some concluding remarks.

\section{The Host Economy}

Consider an economy where competitive firms produce the output with the inputs high and low skilled labor $H$ and $L$ according to a CES production function:

$$
Y=A\left[\alpha H^{\rho}+(1-\alpha) L^{\rho}\right]^{1 / \rho}
$$

where $\rho>0$, which is the empirically more relevant case of gross substitutability of skills (Johnson, 1997; Card \& Lemieux, 2001).

The native population comprises high and low skilled workers in amounts $N_{H}$ and $N_{L}$, respectively. The number of high skilled immigrants is $M_{H}$. The labor market for the high skilled is perfectly competitive, ensuring full employment for these people by full flexibility of the wage $w_{H}$. Hence, the following results are not based on some malfunctioning in this labor market segment.

The low skilled labor market, however, is distorted. The low skilled wage $w_{L}$ is determined by a standard monopoly union model (Layard et al., 1991), where unions act at the firm level in order to maximize a weighted surplus of members' per capita net income and employment $L$ relative to the reference situation. As both unions and firms are small relative to the economy, this reference situation is characterized by full lay-off with all members receiving an unemployment benefit $b$. Letting $\tau$ denote the contribution rate to unemployment insurance, the union objective reads:

$$
\Omega=\log \left[(1-\tau) w_{L}-b\right]+\log L
$$


Once the union has determined the low skilled wage, the firm hires both types of labor according to the respective marginal productivity conditions:

$$
\begin{aligned}
& \frac{\partial Y}{\partial H}=A\left[\alpha\left(N_{H}+M_{H}\right)^{\rho}+(1-\alpha) L^{\rho}\right]^{\frac{1}{\rho}-1} \alpha\left(N_{H}+M_{H}\right)^{\rho-1}=w_{H}, \\
& \frac{\partial Y}{\partial L}=A\left[\alpha\left(N_{H}+M_{H}\right)^{\rho}+(1-\alpha) L^{\rho}\right]^{\frac{1}{\rho}-1}(1-\alpha) L^{\rho-1}=w_{L},
\end{aligned}
$$

where both $L$ and $w_{H}$ adjust for equilibrium, the high skilled wage warranting $H=N_{H}+M_{H}$. It is straightforward to show that both $L$ and $w_{H}$ decrease in the low skilled wage.

Unions anticipate this behavior when setting $w_{L}$. Hence, they maximize (2) subject to (4) which leads to the first-order condition: ${ }^{2}$

$$
\frac{(1-\tau)}{(1-\tau) w_{L}-b}+\frac{\partial L}{\partial w_{L}} \frac{1}{L}=0 .
$$

Considering the fact that aggregate low skilled labor demand cannot exceed aggregate supply, (5) can be written as the aggregate wage setting equation:

$$
W S=(1-\tau) w_{L}(1+\varepsilon)-\varepsilon b \leq 0, \text { with }=0 \text { if } w_{L} \geq w_{L}^{*},
$$

where $w_{L}^{*}$ denotes the full employment wage and:

$$
\varepsilon=\frac{\partial L}{\partial w_{L}} \frac{w_{L}}{L}=\frac{\alpha H^{\rho}+(1-\alpha) L^{\rho}}{(\rho-1) \alpha H^{\rho}}
$$

is the (own) wage elasticity of low skilled labor demand. Due to the gross substitutability property $(\rho>0)$, low skilled labor demand is always elastic $(\varepsilon<-1)$, but is the less elastic the more high skilled labor exists:

$$
\frac{\partial \varepsilon}{\partial H}=\frac{(1-\alpha) \rho L^{\rho}}{\alpha(1-\rho) H^{\rho-1}}>0
$$

Equation (6) has the well known interpretation that the low skilled net wage is a markup $\varepsilon /((1-\tau)(1+\varepsilon))$ on the unemployment benefit, the income in the reference situation. As a higher labor demand elasticity implies higher employment losses from a given wage increase, the markup - and hence the gross wage - is inversely related to $\varepsilon$.

2 Simple, but tedious algebra shows that the second-order condition is fulfilled. 
Accordingly, both an increase of the unemployment benefit and the tax rate reduce the preferred employment level, as either the reference payment or the markup itself increases:

$$
\left.\frac{\partial L}{\partial b}\right|_{W S}=-\overbrace{(>0)}^{\overbrace{\partial W S / \partial b}^{(>0)}}<0,\left.\quad \frac{\partial L}{\partial W S / \partial L}\right|_{W S}=-\frac{\overbrace{\partial W S / \partial \tau}^{(>0)}}{\underbrace{\partial W S / \partial L}_{(>0)}}<0 .
$$

While the unemployment benefit is exogenous from the perspective of the small unions, it has to be funded in the aggregate. This is accomplished by taxing low and high skilled earnings at rates $\tau \in[0,1)$ and $\delta \tau, \delta \in[0,1 / \tau)$, respectively. Thus, the welfare state is actuarial unfair if $\delta>0$ for in that case the high skilled pay contributions to a scheme from which they never receive any benefits.

Utilizing (3), the unemployment insurance budget constraint $b\left(N_{L}-L\right)=\tau w_{L} L+$ $\delta \tau w_{H} H$ can be written as a budget balance equation:

$$
B B=b-\frac{\tau w_{L} L}{\left(N_{L}-L\right)}\left[1+\frac{\delta \alpha}{1-\alpha}\left(\frac{H}{L}\right)^{\rho}\right]=0 .
$$

The unemployment benefit equals the contributions by the low skilled workers per unemployed, augmented by the income share of the high skilled as far as is fiscally relevant $(\delta>0)$.

The reaction of the unemployment benefit on a rise in low skilled employment for a given contribution/tax rate $\tau$ :

$$
\left.\frac{\partial b}{\partial L}\right|_{B B}=-\frac{\partial B B}{\partial L}=\frac{b}{N_{L}-L}+\frac{b}{L}\left(1+\frac{1}{\varepsilon}\right)-b \frac{\rho \delta \alpha H^{\rho}}{L\left(\delta \alpha H^{\rho}+(1-\alpha) L^{\rho}\right)}
$$

results from the interplay of a number of effects. The first term in (11) reflects the fact that each low skilled leaving unemployment allows the existing welfare state revenue to be spread among less recipients. Ceteris paribus, this increases the benefit per unemployed. The second term measures the effect of this additional worker on total low skilled contributions. This effect is also positive because labor demand is elastic $(\varepsilon<-1)$. But third, the income share of the high skilled decreases with low skilled employment:

$$
\frac{\partial\left(w_{H} H\right) /\left(w_{L} L\right)}{\partial L}=-\frac{\rho \delta \alpha}{(1-\alpha) L}\left(\frac{H}{L}\right)^{\rho}<0
$$


This has negative repercussions for welfare state revenues to the extent that the high skilled contribute. As a consequence, the effect of a marginal rise in low skilled employment on the unemployment benefit can not be unambiguously signed. Nevertheless, the benefit becomes infinitely high as the economy approaches full low skilled employment as the number of recipients boils down to zero. Hence, a sufficiently large employment increase must increase $b$.

We are now in the position to derive the labor market equilibrium which is characterized by the mutual compatibility of (6) and (10).

Proposition 1. For every $\tau \in[0,1)$, there exists at least one labor market equilibrium. There is low skilled unemployment in equilibrium whenever $\tau>0$.

Proof. follows from the fact that WS is a continuous function in $(L, b)$-space, with $L=N_{L}$ for $b<\max \left[b^{*}, 0\right]$ where $b^{*}$ denotes the benefit level for which $w_{L}=$ $w_{L}^{*}$ according to WS. For $b \geq \max \left[b^{*}, 0\right], L$ decreases continuously in $b$, see (9), with $\lim _{b \rightarrow \infty} L=0$. For $\tau=0$, BB coincides with the $L$-axis, hence equilibrium employment amounts to $N_{L}$. For $\tau>0$, BB is continuous in $(L, b)$-space, with $b=\frac{\delta \tau \alpha^{1 / \rho}}{N_{L}}$ for $L=0$ whereas $\lim _{L \rightarrow N_{L}} b=\infty$. Hence, BB must cut WS at least once from below in $(L, b)$-space and all intersections must feature $L<N_{L}$.

Hence, the welfare state scheme is ultimately responsible for equilibrium unemployment. Without any social protection, full employment would arise because the union objective would be equivalent to the low skilled wage bill. Labor demand being elastic everywhere, the wage bill increases monotonously in the low skilled employment level and would consequently be maximized by the full employment wage. But whenever the tax rate is positive, some low skilled must be jobless in any equilibrium. This holds because full employment would imply an infinitely high benefit. This in turn would induce unions to set an infinitely high wage. Thus, full employment can never constitute an equilibrium.

Due to the properties of the government budget constraint, multiple equilibria can not be ruled out. However, the argumentation in the above proof reveals that there must be at least one equilibrium where BB intersects WS from below in $(L, b)$ space. Analytically speaking, the determinant of the system is negative for that equilibrium: 


$$
\begin{aligned}
|D|= & \frac{\partial W S}{\partial b} \frac{\partial B B}{\partial L}-\frac{\partial B B}{\partial b} \frac{\partial W S}{\partial L} \\
= & \frac{\tau w_{L}}{\left(N_{L}-L\right)^{2}}\left[(1+\varepsilon) N_{L}-L\right]\left(1+\frac{\delta \alpha}{1-\alpha}\left(\frac{H}{L}\right)^{\rho}\right) \\
& +\frac{\varepsilon \tau w_{L}}{\left(N_{L}-L\right)} \rho \frac{\delta \alpha}{1-\alpha}\left(\frac{H}{L}\right)^{\rho}-\frac{(1-\tau) w_{L}}{L}\left[\frac{1+\varepsilon}{\varepsilon}-\frac{\partial \varepsilon}{\partial L} \frac{L}{\varepsilon}\right]<0 .
\end{aligned}
$$

In what follows, we confine our attention to an equilibrium of this type and omit the case $|D|>0$. This can be justified by two reasons. First, existence of equilibrium is ensured for (13) but not for the opposite case. Second, a negative determinant leads to conventional economic effects in the absence of immigration whereas a positive determinant does not. To illustrate, consider a decrease of actuarial fairness $(\delta \uparrow)$, boosting welfare state revenues for given employment levels. According to the intuition behind (6), low skilled employment should decline because unions charge higher wages as the reference situation improves ceteris paribus. However, this happens only when (13) holds:

$$
\frac{\partial L}{\partial \delta}=\frac{1}{|D|}[-\underbrace{\frac{\partial W S}{\partial b}}_{(>0)} \underbrace{\frac{\partial B B}{\partial \delta}}_{(<0)}] \lesseqgtr 0 \quad \Longleftrightarrow \quad|D| \lesseqgtr 0 .
$$

Hence, by restricting the consideration to an equilibrium with a negative determinant, the upcoming results are derived in a setup which delivers economic mainstream results in other dimensions.

\section{The Effects of Immigration}

This section addresses the consequences of high skilled immigration for employment and the total income of natives.

Proposition 2. High skilled immigration reduces low skilled employment.

Proof. Low skilled employment reacts according to:

$$
\begin{aligned}
\frac{d L}{d M_{H}} & =\frac{\partial W S / \partial H \cdot \partial B B / \partial b-\partial W S / \partial b \cdot \partial B B / \partial M_{H}}{|D|} \\
& =\underbrace{\frac{1}{|D|}}_{<0}[\underbrace{-\frac{(1-\tau) w_{L}}{\varepsilon} \frac{\partial \varepsilon}{\partial H}}_{(>0)}-\delta \underbrace{\frac{\rho \varepsilon \alpha \tau w_{L}}{(1-\alpha)\left(N_{L}-L\right)} H^{\rho-1} L^{-\rho-1}}_{(<0)}] \cdot \square
\end{aligned}
$$


The economic mechanisms behind this result are simple. First, the stronger presence of the high skilled makes low skilled labor demand less elastic. This increases the markup for a given benefit, hence unions demand higher wages and low skilled employment declines. Second, a higher population share of the high skilled increases their contribution relative to the low skilled: $\left(\frac{\partial\left(w_{H} H\right) /\left(w_{L} L\right)}{\partial H}>0\right.$, the inverse to (12). Whenever $\delta>0$, this brings about higher fiscal redistribution via unemployment insurance. The concomitant increase in the unemployment benefit generates a further increase in wage demands. Hence both effects work in the same direction.

This employment contraction is contentious for the immigration surplus (Borjas, 1999), measured by the change in aggregate income of natives. The total income of natives for given $M_{H}$ amounts to:

$$
\begin{aligned}
T N I & =(1-\delta \tau) w_{H} N_{H}+(1-\tau) w_{L} N_{L}+\left(N_{L}-L\right) b \\
& =w_{H} N_{H}+w_{L} L+\delta \tau w_{H} M_{H},
\end{aligned}
$$

the sum of native gross earnings plus immigrants' net fiscal contribution.

Proposition 3. Whenever the welfare state is not too actuarially unfair, marginal immigration decreases total native income.

Proof. The effect of an additional immigrant is:

$$
\frac{\partial T N I}{\partial M_{H}}=\frac{\partial w_{H}}{\partial H} N_{H}+\frac{\partial w_{L}}{\partial H} L+w_{L} \frac{d L}{d M_{H}}+\delta \tau \frac{\partial w_{H}}{\partial H} M_{H}+\delta \tau w_{H}
$$

For marginal immigration $\left(M_{H}=0\right)$, using $H=N_{H}$ and $\frac{\partial w_{H}}{\partial H} H+\frac{\partial w_{L}}{\partial L} L=0$, becomes:

$$
w_{L} \frac{\partial L}{\partial H}+\delta \tau w_{H}
$$

which is unambiguously negative for $\delta=0$.

There are two effects of marginal immigration on aggregate native income. First, there is a negative output effect, as the immigrant receives $w_{H}$, which is more than he adds to total production $\left(\partial Y / \partial H+w_{L} d L / d M_{H}=w_{H}+w_{L} d L / d M_{H}\right)$. Second, he is a net fiscal contributor to an actuarially unfair welfare state. However, this effect vanishes when $\delta=0$; so the overall impact is negative whenever fiscal redistribution is not too intense, that is $\delta$ is low. 
We have thus identified a situation where high skilled immigration decreases total native income although wages are flexible and the welfare state is outright redistributive. This result differs substantially from a full employment setting. There, marginal immigration would be unambiguously beneficial whenever $\delta>0$, as $\frac{d L}{d M_{H}}$ equals zero for $L=N_{L}$.

\section{Conclusion}

This contribution puts some caution on the conventional wisdom that high skilled immigration is unambiguously beneficial for the receiving country. We have presented circumstances under which low skilled labor market distortions render high skilled immigration a burden for the employment of less qualified individuals. This negative effect can translate into a negative immigration surplus. ${ }^{3}$ But even if the surplus was positive, it would not be because but rather despite the native employment consequences. Therefore, some scepticism about the popular belief of positive spillovers of high skilled immigrants on low skilled employment seems appropriate.

By changing the perspective to sending countries, our result provides another source for positive effects of a brain drain, complementary to studies emphasizing positive effects on skill formation (Mountford, 1997). In our model, high skilled emigration would have a positive aggregate effect on the source country provided its welfare state has little redistribution. However, acknowledging that migration is driven by redistribution differentials, the consequences of high skilled mobility become much less clear-cut. It is easy to devise of a situation where the migration of high skilled from a high to a lox tax country hurts both the home country because of the loss in fiscal contributions, and the receiving country because of higher low skilled unemployment.

3 Note that our result does not mean that increasing the number of high skilled natives would have adverse effects on the natives as a whole, as the income gain of the educated would be included in our welfare measure (14). 


\section{References}

Andersson, F. \& Konrad, K.A. (2003), Globalization and Risky Human-Capital Investment, International Tax and Public Finance 10, 211-228.

Bhagwati, J. \& Hamada, K. (1974), The Brain Drain, International Integration of Markets for Professionals and Unemployment: A Theoretical Analysis, Journal of Development Economics 1, 19-42.

Borjas, G. (1999), The Economics of Immigration, in: Ashenfelter, O. and D. Card (eds.), Handbook of Labor Economics 3, Elsevier, 1967-1760.

Card, D. \& Lemieux, T. (2001), Can Falling Supply Explain the Rising Return to College for Younger Men? A Cohort-based Analysis, Quarterly Journal of Economics 116, 705-746.

Chiswick, B.R. (2007), High Skilled Immigration in the International Arena, in: T.R. Shastri (ed.), Emigration: Economic Implications, Icfai University Press, 84-95

Haupt, A. \& Janeba, E. (2008), Education, Redistribution and the Threat of Brain Drain, International Tax and Public Finance, forthcoming

Johnson, G. (1997), Changes in Earnings Inequality: the Role of Demand Shifts, Journal of Economic Perspectives 11, 41-54.

Layard, R., S. Nickell \& R. Jackman (1991), Unemployment. Macroeconomic Performance and the Labor Market, Oxford University Press.

Michael, M. S. (2006), Are Migration Policies that Induce Skilled (Unskilled) Migration Beneficial (Harmful) for the Host Country? CESifo Working Paper 1184.

Mountford, A. (1997), Can a Brain Drain be Good for Growth in the Source Economy?, Journal of Development Economics 53, 287-303.

OECD (2002), International Mobility of the Highly Skilled, OECD Proceedings.

Poutvaara, P. (2000), Education, Mobility of Labour and Tax Competition, International Tax and Public Finance 7, 699-719

Wildasin, D.E. (2000), Labor Market Integration, Investment in Risky Human Capital, and Fiscal Competition, American Economic Review 90, 73-95. 


\section{CESifo Working Paper Series}

for full list see www.cesifo-group.org/wp

(address: Poschingerstr. 5, 81679 Munich, Germany, office@cesifo.de)

2349 Lammertjan Dam and Ben J. Heijdra, The Environmental and Macroeconomic Effects of Socially Responsible Investment, July 2008

2350 Avner Greif, Contract Enforcement and Institutions among the Maghribi Traders: Refuting Edwards and Ogilvie, July 2008

2351 Helmuth Cremer, Philippe De Donder, Dario Maldonado and Pierre Pestieau, Habit Formation and Labor Supply, July 2008

2352 Francesco Menoncin and Paolo M. Panteghini, The Johansson-Samuelson Theorem in General Equilibrium: A Rebuttal, July 2008

2353 Michael Kaganovich and Itzhak Zilcha, Alternative Social Security Systems and Growth, July 2008

2354 Keith Blackburn, Kyriakos C. Neanidis and M. Emranul Haque, Corruption, Seigniorage and Growth: Theory and Evidence, July 2008

2355 Edward Castronova, A Test of the Law of Demand in a Virtual World: Exploring the Petri Dish Approach to Social Science, July 2008

2356 Harald Badinger and Peter Egger, GM Estimation of Higher-Order Spatial Autoregressive Processes in Cross-Section Models with Heteroskedastic Disturbances, July 2008

2357 Wolfgang Buchholz and Jan Schumacher, Discounting the Long-Distant Future: A Simple Explanation for the Weitzman-Gollier-Puzzle, July 2008

2358 Luca Anderlini, Leonardo Felli and Alessandro Riboni, Statute Law or Case Law?, July 2008

2359 Guglielmo Maria Caporale, Davide Ciferri and Alessandro Girardi, Are the Baltic Countries Ready to Adopt the Euro? A Generalised Purchasing Power Parity Approach, July 2008

2360 Erkki Koskela and Ronnie Schöb, Outsourcing of Unionized Firms and the Impacts of Labour Market Policy Reforms, July 2008

2361 Francisco Alvarez-Cuadrado and Ngo Van Long, A Permanent Income Version of the Relative Income Hypothesis, July 2008

2362 Gabrielle Demange, Robert Fenge and Silke Uebelmesser, Financing Higher Education and Labor Mobility, July 2008 
2363 Alessandra Casarico and Alessandro Sommacal, Labor Income Taxation, Human Capital and Growth: The Role of Child Care, August 2008

2364 Antonis Adam, Manthos D. Delis and Pantelis Kammas, Fiscal Decentralization and Public Sector Efficiency: Evidence from OECD Countries, August 2008

2365 Stefan Voigt, The (Economic) Effects of Lay Participation in Courts - A Cross-Country Analysis, August 2008

2366 Tobias König and Andreas Wagener, (Post-)Materialist Attitudes and the Mix of Capital and Labour Taxation, August 2008

2367 Ximing Wu, Andreas Savvides and Thanasis Stengos, The Global Joint Distribution of Income and Health, August 2008

2368 Alejandro Donado and Klaus Wälde, Trade Unions Go Global!, August 2008

2369 Hans Gersbach and Hans Haller, Exit and Power in General Equilibrium, August 2008

2370 Jan P.A.M. Jacobs and Jan-Egbert Sturm, The Information Content of KOF Indicators on Swiss Current Account Data Revisions, August 2008

2371 Oliver Hülsewig, Johannes Mayr and Timo Wollmershäuser, Forecasting Euro Area Real GDP: Optimal Pooling of Information, August 2008

2372 Tigran Poghosyan and Jakob de Haan, Determinants of Cross-Border Bank Acquisitions in Transition Economies: A Latent Class Analysis, August 2008

2373 David Anthoff and Richard S.J. Tol, On International Equity Weights and National Decision Making on Climate Change, August 2008

2374 Florian Englmaier and Arno Schmöller, Reserve Price Formation in Online Auctions, August 2008

2375 Karl Farmer, Birgit Friedl and Andreas Rainer, Effects of Unilateral Climate Policy on Terms of Trade, Capital Accumulation, and Welfare in a World Economy, August 2008

2376 Monika Bütler, Stefan Staubli and Maria Grazia Zito, The Role of the Annuity’s Value on the Decision (Not) to Annuitize: Evidence from a Large Policy Change, August 2008

2377 Inmaculada Martínez-Zarzoso, The Impact of Urbanization on $\mathrm{CO}_{2}$ Emissions: Evidence from Developing Countries, August 2008

2378 Brian Roberson and Dmitriy Kvasov, The Non-Constant-Sum Colonel Blotto Game, August 2008

2379 Ian Dew-Becker, How Much Sunlight Does it Take to Disinfect a Boardroom? A Short History of Executive Compensation Regulation, August 2008 
2380 Cécile Aubert, Oliver Falck and Stephan Heblich, Subsidizing National Champions: An Evolutionary Perspective, August 2008

2381 Sebastian Buhai, Miguel Portela, Coen Teulings and Aico van Vuuren, Returns to Tenure or Seniority?, August 2008

2382 Erkki Koskela and Jan König, Flexible Outsourcing, Profit Sharing and Equilibrium Unemployment, August 2008

2383 Torberg Falch and Justina AV Fischer, Does a Generous Welfare State Crowd out Student Achievement? Panel Data Evidence from International Student Tests, September 2008

2384 Pedro Gomes and François Pouget, Corporate Tax Competition and the Decline of Public Investment, September 2008

2385 Marko Koethenbuerger, How Do Local Governments Decide on Public Policy in Fiscal Federalism? Tax vs. Expenditure Optimization, September 2008

2386 Ronald McKinnon and Gunther Schnabl, China’s Exchange Rate Impasse and the Weak U.S. Dollar, September 2008

2387 Yan-Leung Cheung, Yin-Wong Cheung and Alan T.K. Wan, A High-Low Model of Daily Stock Price Ranges, September 2008

2388 Louis Eeckhoudt and Harris Schlesinger, Changes in Risk and the Demand for Saving, September 2008

2389 Carsten Hefeker and Blandine Zimmer, Uncertainty and Fiscal Policy in an Asymmetric Monetary Union, September 2008

2390 Jay Pil Choi and Byung-Cheol Kim, Net Neutrality and Investment Incentives, September 2008

2391 Marcel Gérard, Financing Bologna, the Internationally Mobile Students in European Higher Education, September 2008

2392 Annette Alstadsæter and Knut Reidar Wangen, Corporations' Choice of Tax Regime when Transition Costs are Small and Income Shifting Potential is Large, September 2008

2393 António Afonso and Christophe Rault, 3-Step Analysis of Public Finances Sustainability: the Case of the European Union, September 2008

2394 Betsey Stevenson and Justin Wolfers, Economic Growth and Subjective Well-Being: Reassessing the Easterlin Paradox, September 2008

2395 Bernhard Eckwert and Itzhak Zilcha, Private Investment in Higher Education: Comparing Alternative Funding Schemes, September 2008 
2396 Øystein Foros, Hans Jarle Kind and Jan Yngve Sand, Slotting Allowances and Manufacturers’ Retail Sales Effort, September 2008

2397 Mohammad Reza Farzanegan, Illegal Trade in the Iranian Economy: Evidence from a Structural Model, September 2008

2398 Olivier Bos, Charity Auctions for the Happy Few, September 2008

2399 Robert S. Chirinko and Debdulal Mallick, The Marginal Product of Capital: A Persistent International Puzzle, September 2008

2400 Ben D’Exelle and Arno Riedl, Elite Capture, Political Voice and Exclusion from Aid: An Experimental Study, September 2008

2401 Torben M. Andersen and Joydeep Bhattacharya, On Myopia as Rationale for Social Security, September 2008

2402 Fabienne Llense, French CEO Compensations: What is the Cost of a Mandatory Upper Limit?, September 2008

2403 Valentina Bosetti, Carlo Carraro, Alessandra Sgobbi and Massimo Tavoni, Delayed Action and Uncertain Targets. How Much Will Climate Policy Cost?, September 2008

2404 Robert G. Chambers, Rolf Färe, Shawna Grosskopf and Michael Vardanyan, Generalized Quadratic Revenue Functions, September 2008

2405 Leonidas Enrique de la Rosa, Overconfidence in a Career-Concerns Setting, September 2008

2406 Marcus Drometer and Johannes Rincke, The Design of Political Institutions: Electoral Competition and the Choice of Ballot Access Restrictions in the United States, September 2008

2407 Markku Lanne and Helmut Lütkepohl, Stock Prices and Economic Fluctuations: A Markov Switching Structural Vector Autoregressive Analysis, September 2008

2408 Thomas L. Brewer, International Energy Technology Transfers for Climate Change Mitigations, September 2008

2409 Alexander Kemnitz, Native Welfare Losses from High Skilled Immigration, September 2008 